\title{
Multi-source-supplied parallel hybrid propulsion of the inland passenger ship STA.H. Research work on energy efficiency of a hybrid propulsion system operating in the electric motor drive mode
}

\author{
Jakub Kowalski, M. Sc. \\ Wojciech Leśniewski, Ph. D. \\ Wojciech Litwin, Ph. D. \\ Gdansk University of Technology, Poland
}

\begin{abstract}
In the Faculty of Ocean Engineering and Ship Technology, Gdansk University of Technology, design has recently been developed of a small inland ship with hybrid propulsion and supply system. The ship will be propelled by a specially designed so called parallel hybrid propulsion system.

The work was aimed at carrying out the energy efficiency analysis of a hybrid propulsion system operating in the electric motor drive mode and at performing the noise pollution measurements.

The performed investigations have shown that a significant impact on the efficiency and on the acoustic emission has the type of belt transmission applied.
\end{abstract}

Key words: hybrid ship propulsion; ship propulsion

\section{INTRODUCTION}

In recent years an unusual development in practically all fields of science has been witnessed. In effect, new machines and equipment with increasing capabilities are being designed and produced and the progress has not left shibuilding out.

In most of the now constructed ships the conventional propulsion with an internal combustion engine is used. Modern propulsion units of the type are equipped with complex fittings limiting emissions of noxious compounds to the atmosphere. Attempts to limit emissions are being made even at the cost of increased fuel consumption. Modern internal combustion engines are more and more often adapted to use such nontypical fuels as vegetable oils or compressed natural gas.

Specific requirements are imposed on the inland navigation ships. Some inland waterways are under particular protection as popular recreation regions or due to their exceptional landscape values.

Looking through the shipbuilding technical literature, one can often come across the terms like "no emission", "zero emission" or "greenship" in titles of the papers. This testifies that the "clean technologies" are now a much more meaningful issue than they used to be.

In the case of a conventional propulsion system, the "noise pollution" is also a significant problem. Unfortunately, even a perfectly designed engine exhaust system cannot fully eliminate noise. Combustion engine is also a source of vibration, which may have a negative impact on the condition of crew and passengers, particularly during a longer voyage. Another problem are the exhaust gases, which with an adverse wind can significantly worsen the sailing comfort.

The electric propulsion has none of the above described flaws. It operates silently and generally is not a source of vibration. In addition, the most up-to-date solutions have a high, 90\% exceeding efficiency. However, a problem is the motor supply source. The use of a combustion engine-driven generating set does not solve the problem, as all the above described limitations will then occur. The fuel cell appears an advisable solution in the case. Such solution was used on a ship already in 1964 [1, 2, 3, 4]. A very interesting ship is Alsterwasser launched in 2008. She is equipped with hydrogensupplied fuel cells.

The same technology has been used also in the 212A class submarines built in 1996 by the Thyssen-Krupp Marine Systems/HDW corporation to the order of the German Navy. They are equipped with the Siemens company hydrogensupplied fuel cells.

Therefore, the information (given at the beginning of 2013) that the Siemens company withdraws from the development work on fuel cells was a big surprise. 


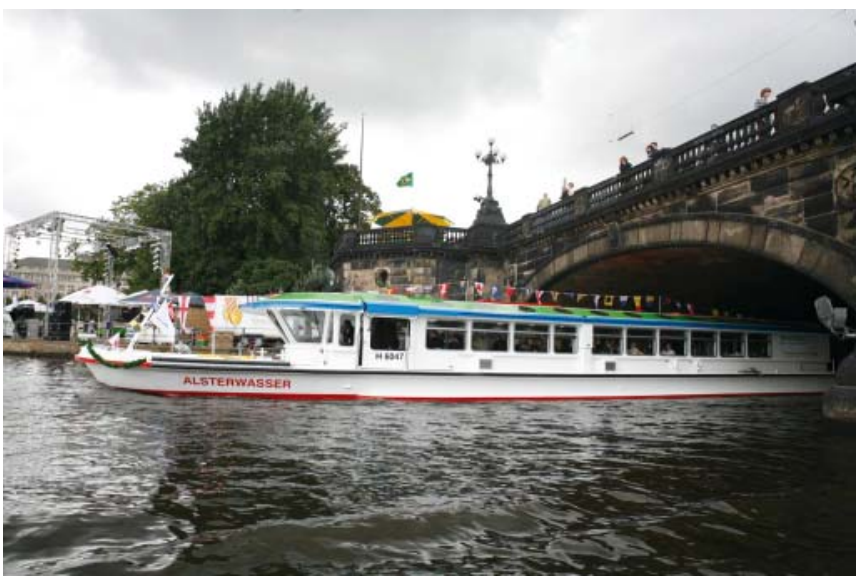

Fig. 1. The Alsterwasser ship launched in 2008 in Hamburg, driven with a $100 \mathrm{~kW}$ electric motor supplied by two $48 \mathrm{~kW}$ fuel cells, may take a hundred passengers on deck (http://www.zemships.eu)

Batteries are a commonly used supply source for electric motors driving small and medium size inland vessels. Unfortunately, the cheapest classical solutions are heavy and the modern light batteries (Fig. 2) are very expensive. The price of an $1 \mathrm{kWh}$ module may exceed a thousand Euro and it depends on the battery generation, manufacturer, and size of the order.

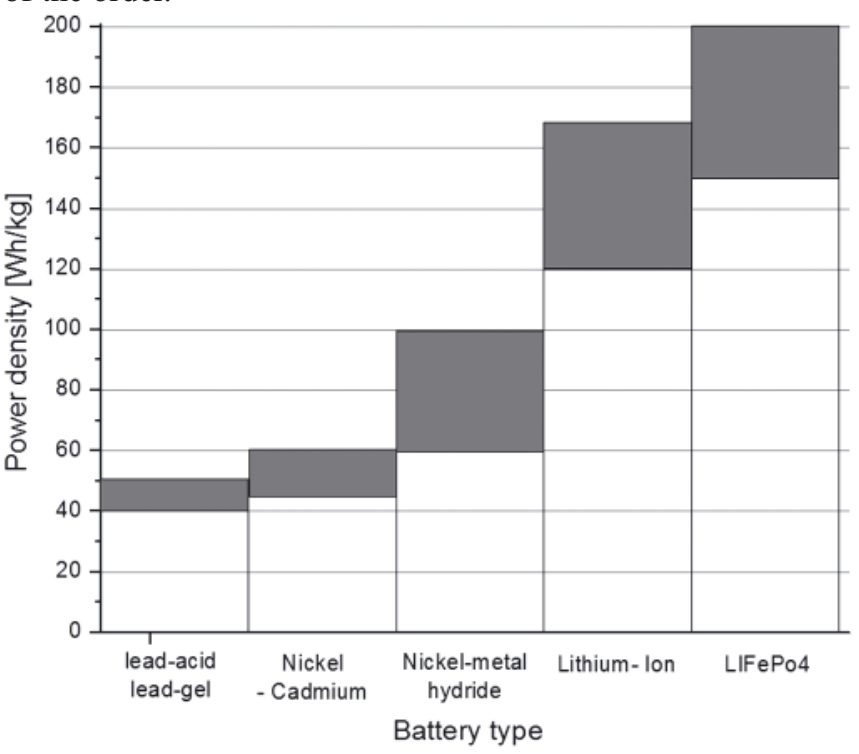

Fig. 2. Energy density of the most popular now available battery types (based on the Authors' investigation - data of 2013)

Therefore, in most of the so far implemented solutions the lead batteries have been applied. But this creates serious problems. A service ship, e.g. a passenger vessel, is usually designed for as intensive operation as possible. It must be a source of income to repay, within a shortest possible time, the expensive investment of its designing and construction. It is also recommended to be relatively fast. Greater speed means greater number of trips, besides, the owners' experience shows that passengers get nervous when, even in touristically attractive surroundings, the trip takes too long. Greater speed means also increased demand for accumulated energy, which translates into large volume and great weight of the batteries. Great weight of batteries means in turn increased ship draught and increased hydrodynamic resistance, i.e. even greater demand for energy. Therefore, proper design of the ship hull, with as little weight as possible and low hydrodynamic resistance, are the basic questions. Very important is also a high-efficiency propulsion system.
As the Authors' experience indicates, in many cases the use of a propulsion system based exclusively on an electric motor is not justified. In preparing the "Design of an ecological watercraft for inland waters in Poland" project for realization, analysis was carried out of several popular sailing routes, with fragments included in the "Nature 2000" programme protection system or protected as parts of a national park. It appeared that quite long sections of waterways are touristically not particularly attractive and there are no navigating speed limits on them. Therefore, the project authors came to the conclusion that an ideal solution would be a hybrid propulsion system, being a combination of a compression ignition engine and an electric motor. Such solution allowed considerable reduction of the ship weight and the propulsion system flexibility.

\section{DESIGN OF THE STA.H SHIP}

The designed ship has $19 \mathrm{~m}$ length, $5 \mathrm{~m}$ width and about $0.5 \mathrm{~m}$ draught and can take on deck from 50 to 70 passengers, depending on version. The main dimensions allow it to navigate on smaller, shallow Polish rivers, as well as on the route from Gdansk to Augustow, where the prototype unit is supposed to operate.

The design of ship is an effect of cooperation between engineers from the Faculty of Ocean Engineering and Ship Technology, Gdansk University of Technology and artists from the Academy of Fine Arts in Gdansk.

Particular effort was made to reduce the hydrodynamic resistance of the ship hull and to minimize draught. Low weight was achieved by designing the hull from aluminium. The tests of hydrodynamic resistance were performed in parallel for two versions - a single hull and a double hull (catamaran) structure. Numerical analysis by CFD method and model tests in the Faculty of Ocean Engineering and Ship Technology towing tank were carried out (Fig. 3).
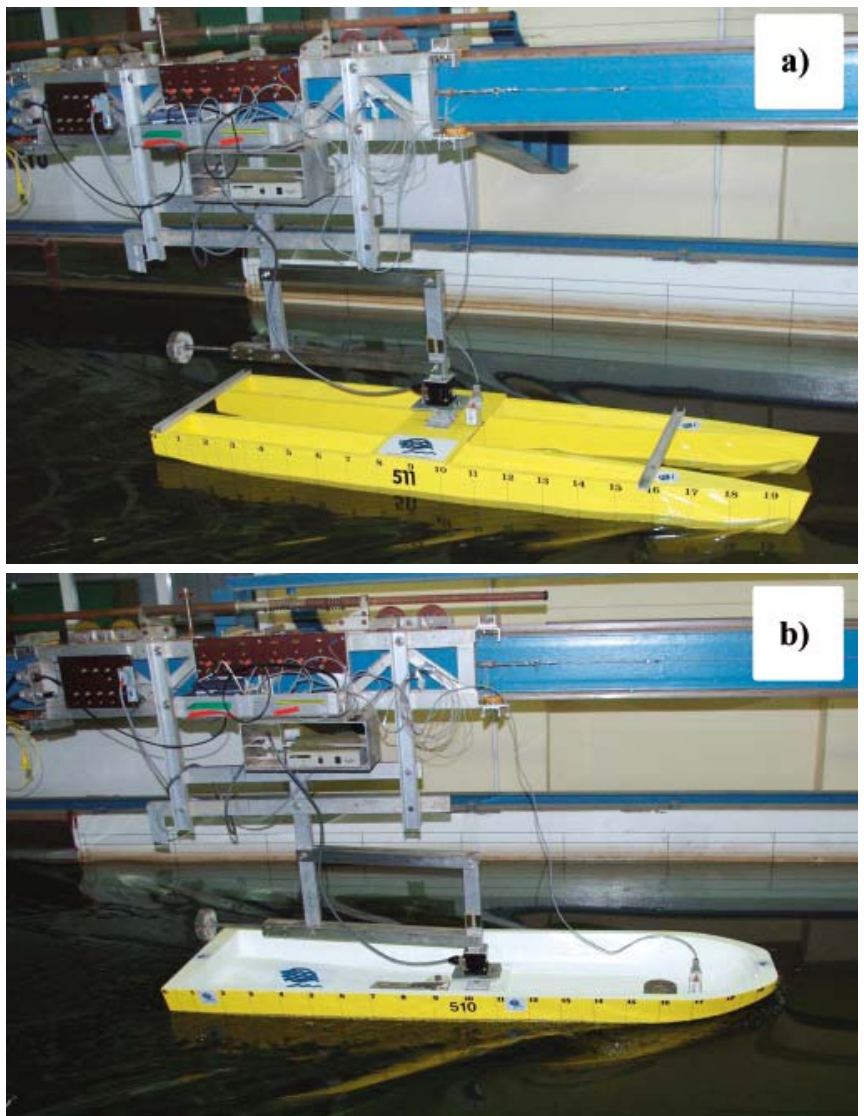

Fig. 3. Model of STA.H ship during the towing tank tests; a) catamaran b) single-hull version; photo: Mirostaw Grygorowicz 
The tests showed that the catamaran had slightly lower hydrodynamic resistance than the single-hull unit. Nevertheless, the single-hull version was considered a more promising solution due to its smaller draught and smaller overall height of the vessel.

The ship propulsion system has been designed in two versions. For fast navigation in the regions with protected sections the parallel hybrid diesel-electric solution is proposed. In the other version, of a ship designed for navigation in fully protected regions, the all-electric propulsion system has been chosen. In both solutions the electric propulsion system is equipped with a hybrid multi-source supply system consisting of a battery, high power charger, photovoltaic panel module on the ship deck and the auxiliary emergency generating set. Both solutions have been accepted by the classification society.

\section{PROPULSION SYSTEM DESIGN}

In the preliminary design stage, the propulsion power and the necessary battery weights were assumed from experience, as the results of hull hydrodynamic resistance tests were not known yet and precise estimation of power demand was impossible (Table 1). It has to be remembered, that because of the classification society requirements regarding high level of safety, two autonomous propulsion systems must be provided. In effect, a twin-screw propulsion system must be applied, which is otherwise advantageous. The most important advantage is smaller diameter of the propulsion screws, important for a small-draught inland vessel. Additionally, a twin-screw ship has better manoeuvrability.

Tab. 1. Data assumed in the preliminary design included the weights of electric system, propulsion system and supply system

\begin{tabular}{|c|c|c|}
\hline No. & Description & $\begin{array}{c}\text { Brief } \\
\text { foredesign }\end{array}$ \\
\hline 1 & $\begin{array}{l}\text { Cruising speed with the electric } \\
\text { motor drive }[\mathrm{km} / \mathrm{h}]\end{array}$ & 8 \\
\hline 2 & Power of the electric drive $[\mathrm{kW}]$ & $2 \times 12$ \\
\hline 3 & $\begin{array}{l}\text { Time of navigating with the electric } \\
\text { drive }[\mathrm{h}]\end{array}$ & 3 \\
\hline 4 & $\begin{array}{l}\text { Battery capacity (with the allowance } \\
\text { taking into account the loss of } \\
\text { capacity) }[\mathrm{kWh}]\end{array}$ & $2 \times 40$ \\
\hline 5 & $\begin{array}{c}\text { Number of batteries }(75 \mathrm{~kg}, 12 \mathrm{~V}, \\
230 \mathrm{Ah})[\mathrm{pcs} .]\end{array}$ & $2 \times 16$ \\
\hline 7 & Battery weight $[\mathrm{kg}]$ & $2 \times 1200$ \\
\hline 8 & $\begin{array}{c}\text { Approximate weight of motors with } \\
\text { fittings }[\mathrm{kg}]\end{array}$ & $2 \times 80$ \\
\hline
\end{tabular}

After the towing tank tests it appeared that the power needed to achieve the required speed is less than the value assumed in the preliminary design. However, it has to be remembered that in real conditions the impact of wind and of the hull overgrowing with water organisms may increase the power demand. Also a certain power reserve in the propulsion system is needed for manoeuvrability purposes. Finally, a three-phase alternating-current electric motor with permanent lantanide series magnets was chosen, which, supplied with $48 \mathrm{~V}$ voltage by means of a dedicated frequency converter, achieves the power of $10 \mathrm{~kW}$. It is also important that, if needed, the motor can operate as generator driven by the main engine and batteries may be charged in this way.
The propulsion system designed by the Authors (Fig. 4) has some important advantages. It can cooperate with typical combustion engines of various power. The designed system may be installed aboard a newbuilt ship or an existing solution may be modernized. The proposed system may also be used as an electric propulsion system without the combustion engine. Another advantage is easy assembly and free access to the electric motor. In practice, the solution allows easy replacement of the drive unit in accordance with customer's demand and does not require significant structural changes.

A complete propulsion system is shown in Fig. 4 below. For the system to operate properly, the combustion engine must be equipped with a typical reduction gear, with coupling allowing to disconnect the engine from the shaft line. Then the electromagnetic clutch (4) may be remotely switched on and the electric drive activated. It is also worth noting that the solution with belt transmission makes it easy to adjust individually the transmission ratio depending on the engine type used, by exchanging the belt pulleys and belt.

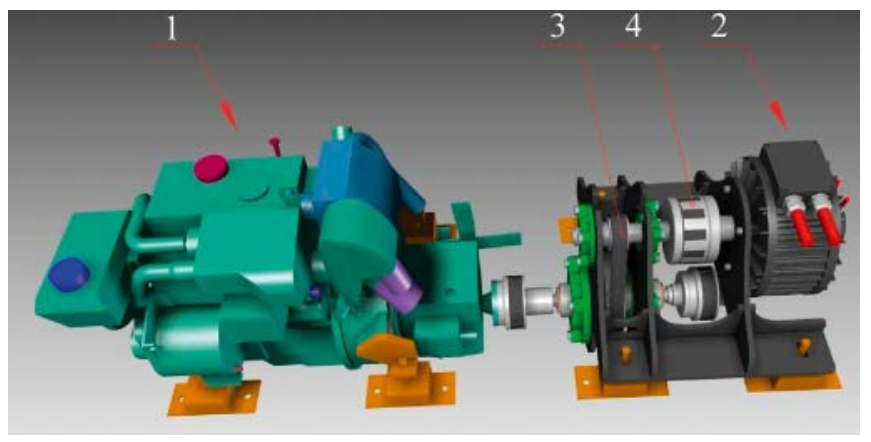

Fig. 4. Visualization of the STA.H ship hybrid propulsion system: 1 - combustion engine with reduction gear, 2 -electric motor, $\mathbf{3}$ - belt transmission, $\mathbf{4}$ - controlled clutch

Similar solutions are now used by established manufacturers. Looking through the catalogues, participating in fairs and exhibitions, one can hear a lot about advantages of this type of drive, particularly about its noiseless operation and high energy efficiency.

\section{INVESTIGATIONS OF A HYBRID SYSTEM OPERATING IN THE ELECTRIC MOTOR DRIVE MODE}

The propulsion system was assembled in the Faculty of Ocean Engineering and Ship Technology laboratory (Fig. 5). Combustion engine was not connected to the hybrid propulsion system test stand, as the test was aimed at evaluation of the propulsion system energy efficiency during the electric motor operation. Therefore, concentration was on the electric drive together with the belt transmission. The propulsion system was loaded with a direct-current generator (pos. 5).

In order to measure the belt transmission and the electric motor efficiency, the controlled clutch (Fig. 4 pos. 4) was replaced by a torque meter (Fig. 5 pos. 2).

The following parameters were recorded during the tests: rotational speed and torque on the motor shaft,

torque on the driven shaft,

voltage and intensity of the motor input current,

noise during the system operation,

temperature distribution on the surface of transmission subassemblies.

After completion of the measurements, it was possible to calculate the power of losses in the transmission gear and 
Tab. 2. Data of the two investigated drive versions

\begin{tabular}{|c|c|c|}
\hline \multirow[b]{2}{*}{ Drive type } & First version (I) & Second version (II) \\
\hline & $\begin{array}{c}\begin{array}{c}\text { Synchronic straight gear belt transmission, } \\
\text { belt width } 30 \mathrm{~mm} \text {, pitch } 8 \mathrm{~mm}\end{array} \\
\end{array}$ & $\begin{array}{c}\text { Synchronic bevel gear belt transmission, } \\
\text { belt width } 32 \mathrm{~mm} \text {, pitch } 8 \mathrm{~mm}\end{array}$ \\
\hline $\begin{array}{l}\text { Transmission ratio / number } \\
\text { of wheel teeth }\end{array}$ & \multicolumn{2}{|c|}{$1: 3.07 / 80$ and 26} \\
\hline $\begin{array}{l}\text { Motor power / motor } \\
\text { rotational speed }\end{array}$ & \multicolumn{2}{|c|}{$10 \mathrm{~kW} / 3000 \mathrm{rev} / \mathrm{min}$} \\
\hline $\begin{array}{l}\text { Safety coefficient assumed } \\
\text { for the drive - service factor }\end{array}$ & \multicolumn{2}{|c|}{1.5} \\
\hline
\end{tabular}

motor, the propulsion system (motor and frequency converter) energy efficiency, the transmission gear efficiency and the overall efficiency of the propulsion system. The results are presented in chapter 5 .

Details of the two investigated drive versions are given in Table 2.

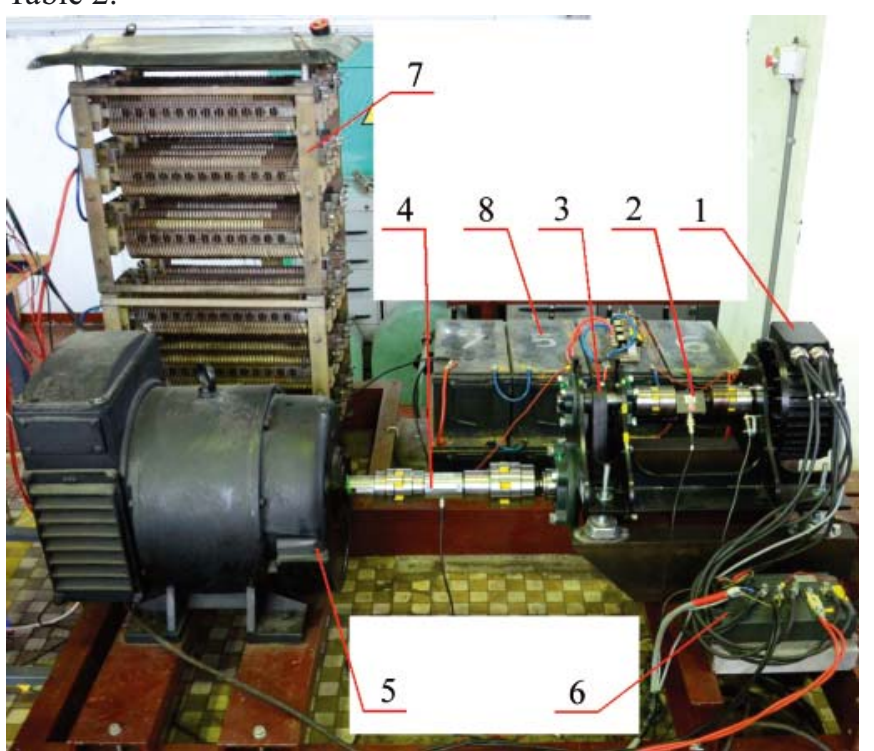

Fig. 5. Test stand for investigations of the hybrid propulsion system operating in the electric drive mode: $\mathbf{1}$-electric motor, $\mathbf{2}$-torque meter installed instead of controlled clutch, 3 - belt transmission, 4 -torque meter, 5 -generator, $\mathbf{6}$ - frequency converter, 7 -resistor

\section{INVESTIGATION RESULTS}

In designing the drive transmission system, no particular difficulties were anticipated and the solution seemed not complicated. In the drive first version (I), a high class synchronic straight gear belt transmission was used consisting of two toothed wheels and one tension roll. In order to be sure that the system will operate properly, recommended by the manufacturer prefabricated belt pulleys were acquired. The small driving wheel had flanged rims protecting against the belt slip-off.

From the beginning of measurements it appeared that the drive transmission system operated with excessive noise (Fig. 6), the noise intensity reached $87 \mathrm{~dB}$.

Temperature of the transmission subassemblies was measured by means of a thermovision camera (Fig. 7 and 8). The measurements were verified by thermocouples ( $\mathrm{Sp} 1$ and Sp2) installed on the transmission gear. Their position was changed in the consecutive measurement series, which can be seen in the illustrations. The measurements showed that temperature of the full power transmitting drive system stabilized after about forty minutes of operation.
During the investigations a new very modern type of synchronic bevel gear belt was acquired. Price of such solution was almost four times higher than that of the above described classic solution. Both solutions were compared. The second (II) version had the wheels without protective rims because of the specific gear geometry. A comparable efficiency but certainly a lower noise level was expected. Results of the measurements of temperature distributions (Fig. 8) and efficiency (Fig. 9 to 11) are presented below.

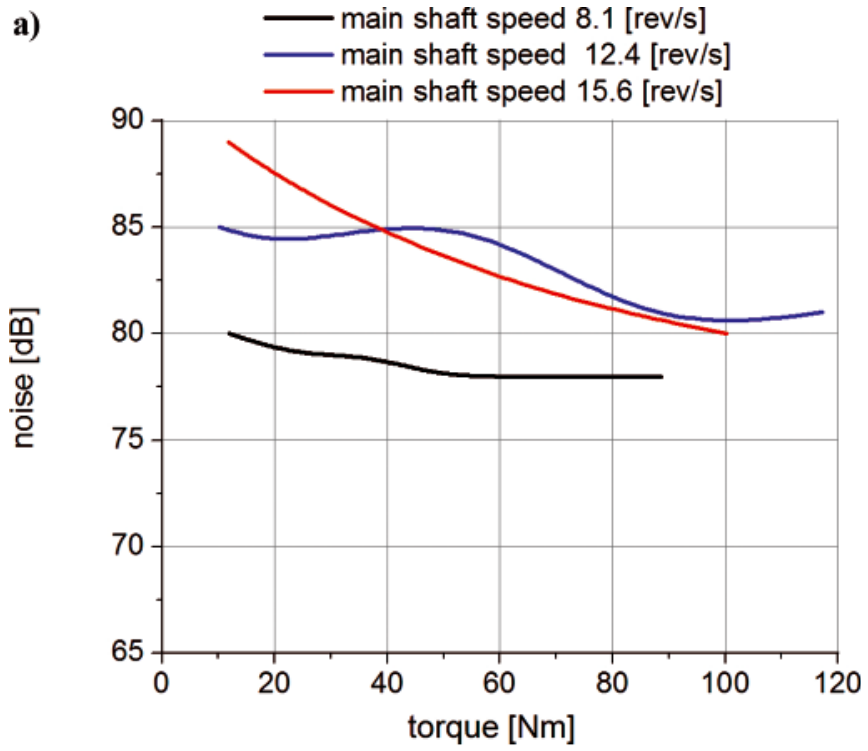

b)

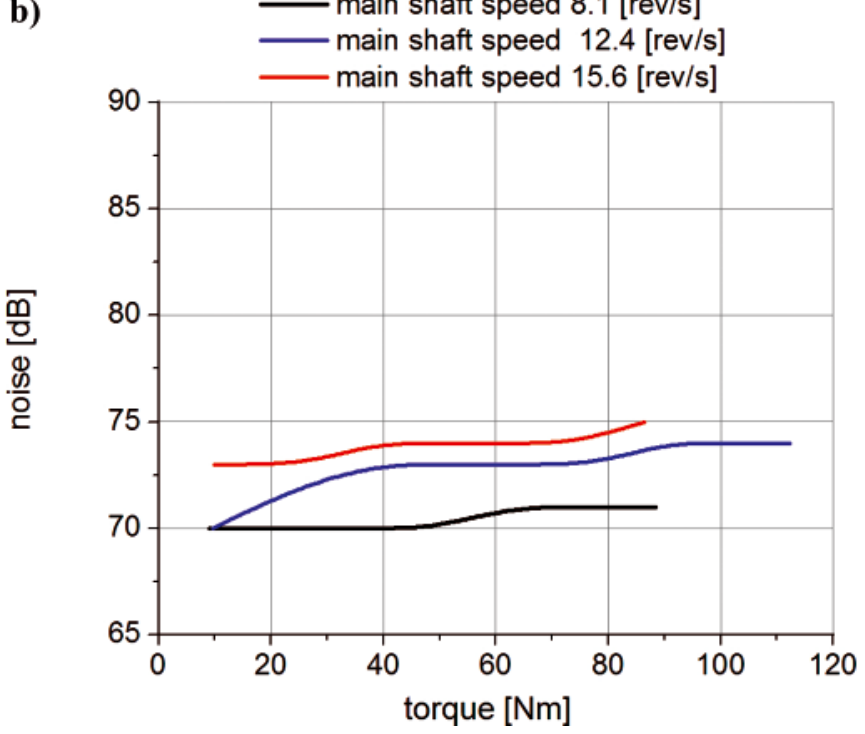

Fig. 6. Diagrams of the measured noise as a function of drive shaft torque and rotational speed: a) version I-straight gear belt,

b) version $I I-$ bevel gear belt 

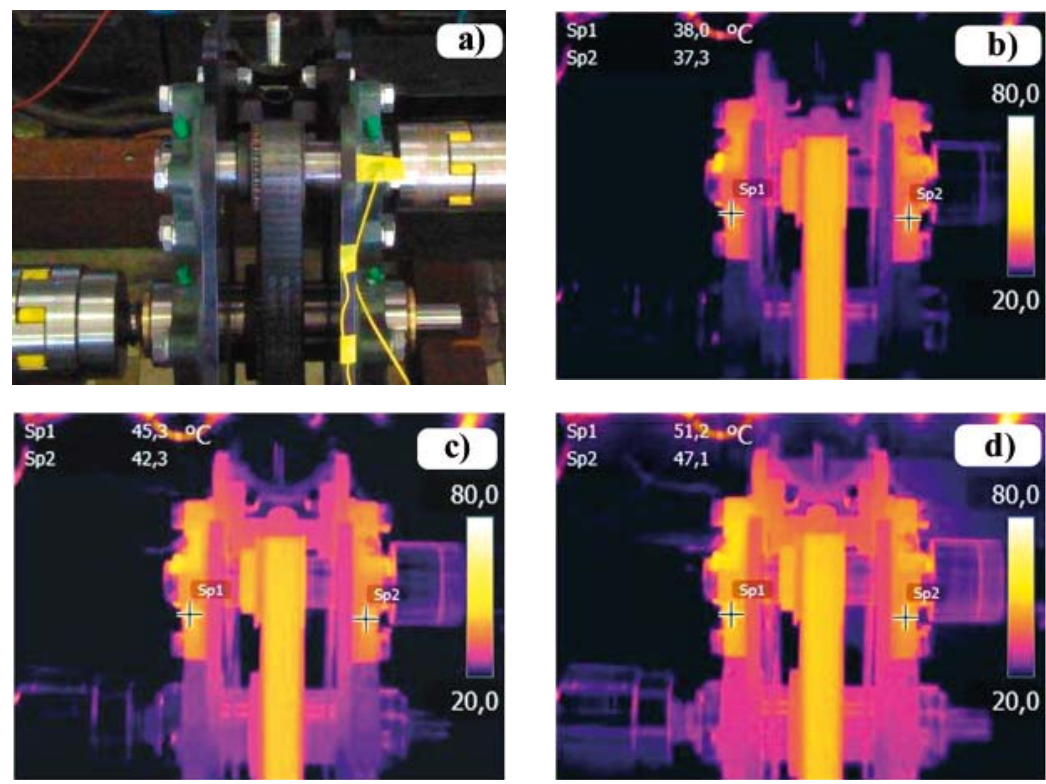

Fig. 7. Results of temperature field measurements carried out with thermovision camera in the transmission version I; a) photograph of the investigated system, $\boldsymbol{b})$ the system immediately after start-up, c) measurement after 20 minutes, d) measurement in stabilized state after 40 minutes of operation
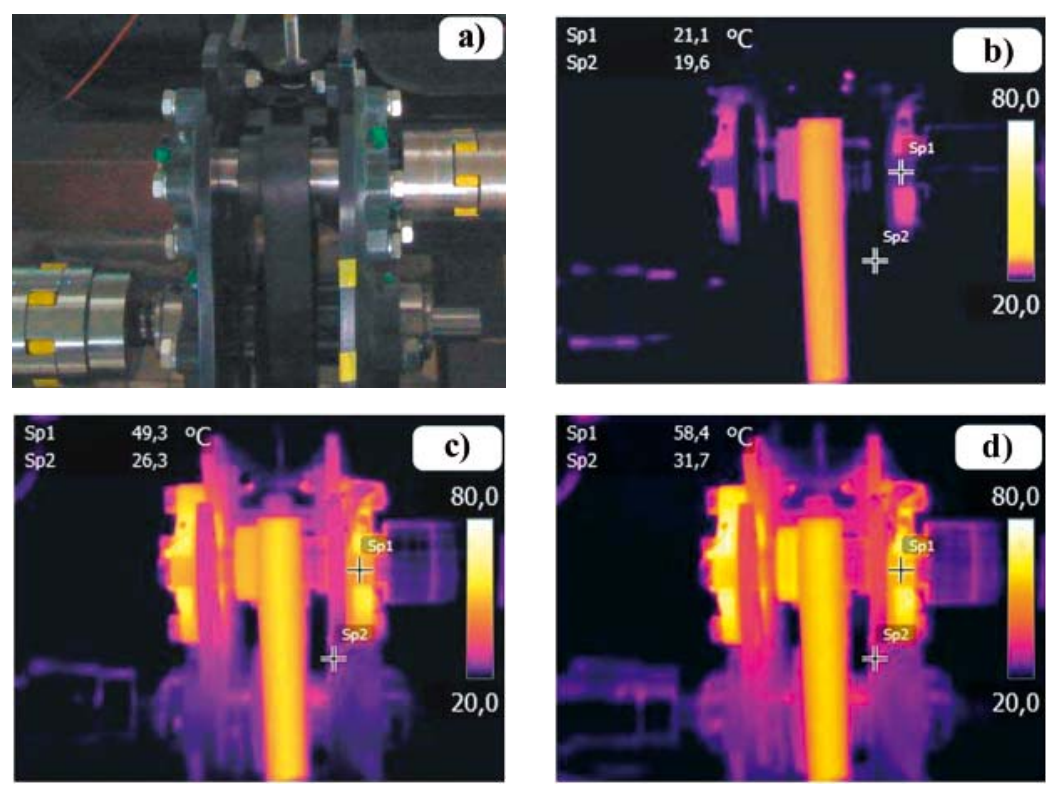

Fig. 8. Results of temperature field measurements carried out with thermovision camera in the transmission version II; a) photograph of the investigated system, $\boldsymbol{b})$ the system immediately after start-up, c) measurement after 20 minutes, d) measurement in stabilized state after 40 minutes of operation

a)

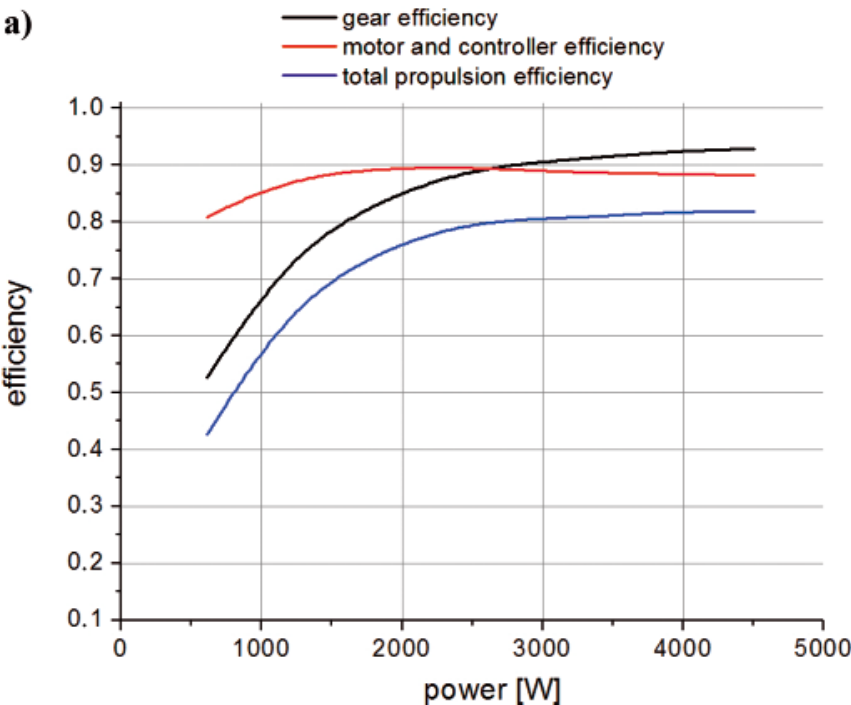

b)

- gear efficiency

- motor and controller efficiency - total propulsion efficiency

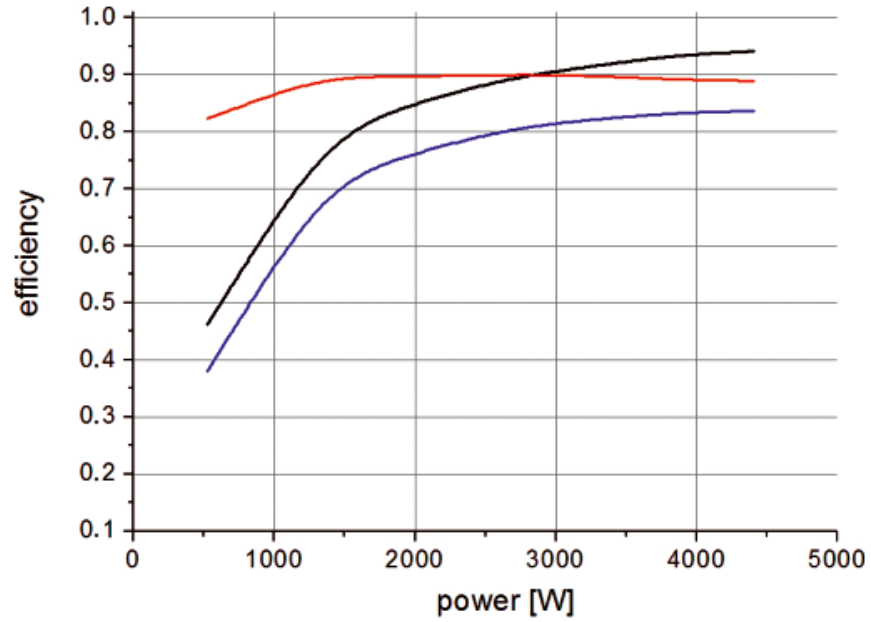

Fig. 9. Diagrams of efficiency as a function of output power for the main shaft speed $n=8.1 \mathrm{rev} / \mathrm{s}$, a) transmission with straight gear belt (version I), b) transmission with bevel gear belt (version II) 
a)
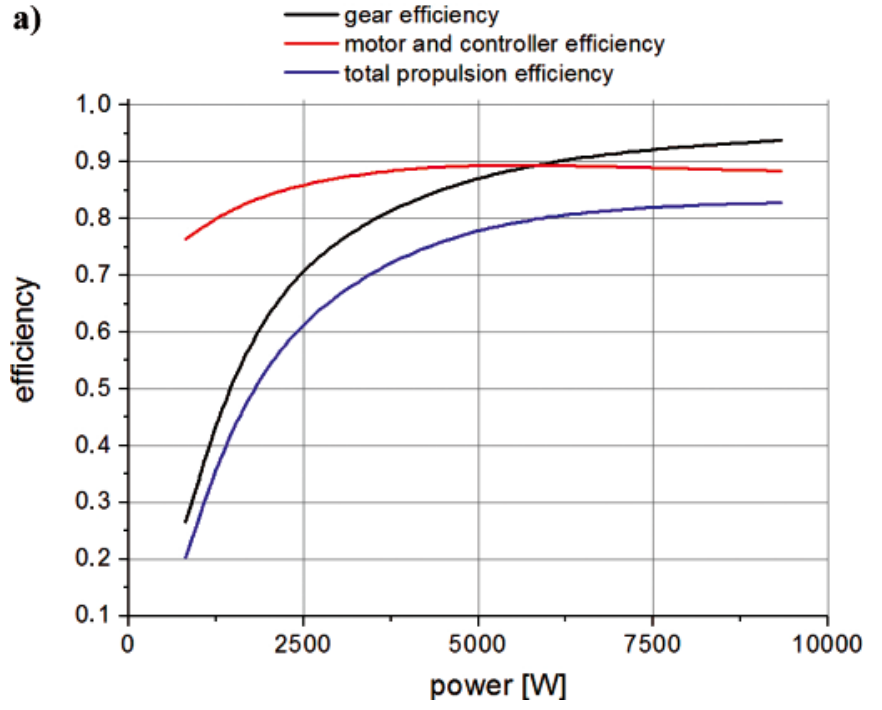

b)

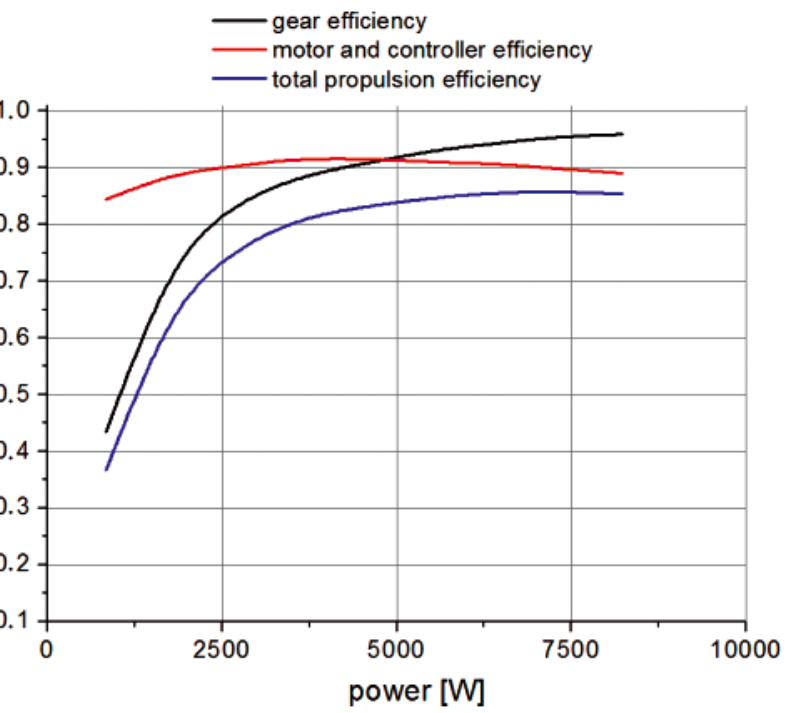

Fig. 10. Diagrams of efficiency as a function of output power for the main shaft speed $n=12.4 \mathrm{rev} / \mathrm{s}$; a) transmission with straight gear belt (version I), b) transmission with bevel gear belt (version II)

a)

a)

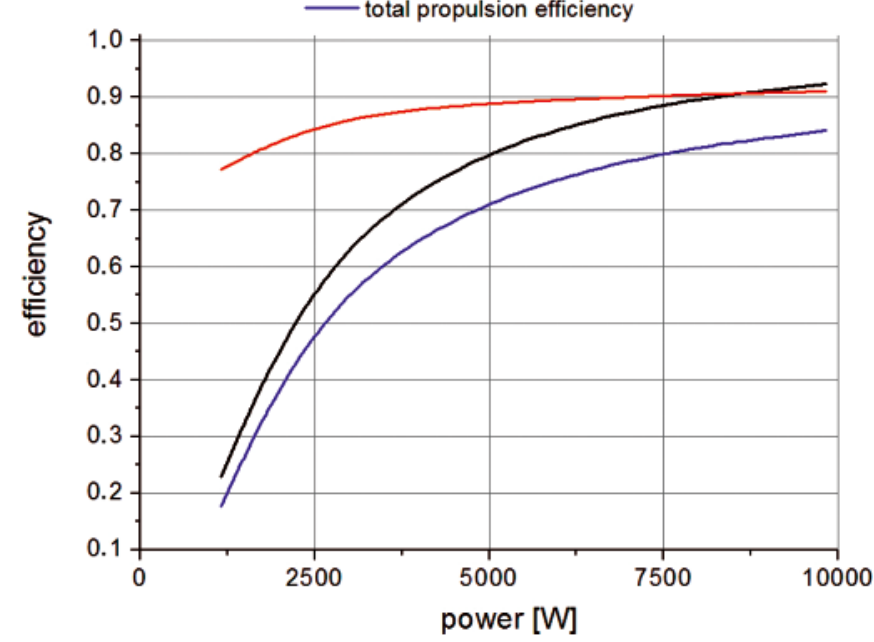

b)

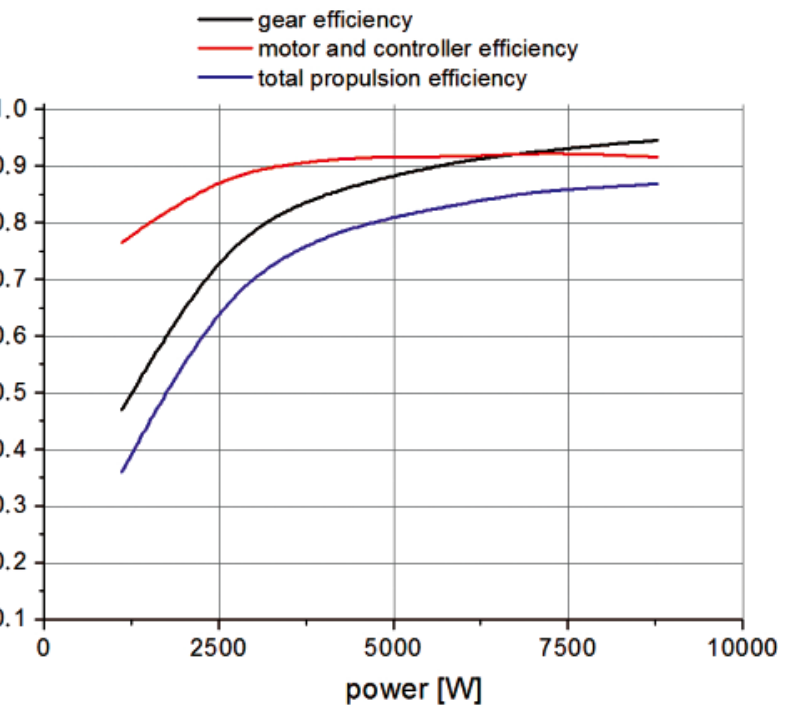

Fig. 11. Diagrams of efficiency as a function of output power for the main shaft speed $n=15.6 \mathrm{rev} / \mathrm{s}$; a) transmission with straight gear belt (version I), b) transmission with bevel gear belt (version II)

\section{DISCUSSION}

The investigation results have shown that the efficiency of such belt transmissions increases with the increasing output power (Fig. 9 to 11). This is relation typical of that type of solutions. The analysis of lost power (Fig. 12 and 13) gives a picture of an interesting phenomenon. It appears that the power of energy losses does not increase with increasing output torque, but slightly decreases. In the Authors' opinion, this may be an effect of stretching the active part of the belt and slight slackening of the passive part where the tension roll is mounted. In effect, resistance on the tension roll is slightly lower. In the case of straight gear belt, the power of losses is proportional to the emitted noise (Fig. 12). Such effect cannot be seen in the transmission system with bevel gear belt, which indicates a different character of the movement resistance. In the Authors' opinion, the main source of losses and of the acoustic emissions in the case of straight gear belt is throttling the tooth space by consecutive belt teeth and making the compressed air come out sidewise. This effect can be limited by removing one flanged rim of the belt pulley or making holes in the rims to let the compressed air out. In the investigated case, removing one rim was not a promising method as the belt was several millimetres narrower than the pulley.

Worth considering is also a conception of not overdimensioning the drive system by assuming a high service factor. In designing the analysed system (after consultation with the manufacturer), the value 1.5 of service factor was assumed. In this way it will be possible to extend the transmission gear operating field in the range where the efficiency exceeds $90 \%$ (Fig. 14). However, this can be achieved at the expense of the drive durability. In the case of a typical inland vessel, which usually has a long winter break in navigation, it does not seem to be a problem as the belt can then be renewed.

In the analysed case (Fig. 14), decreasing the assumed service factor from 1.5 to 1 would cause extending the operating field where efficiency exceeds $90 \%$.

The investigations have shown that the bevel gear belt has higher efficiency than the straight gear belt by about $5 \%$ in the whole range of rotational speed and torque where the tests were carried out. A considerable surprise was noisy operation of the straight gear belt drive system (Fig. 6 and 12), which is surely an effect of the high rotational speed of small wheel reaching $3000 \mathrm{rev} / \mathrm{min}$. 
a) - noise, shaft speed 15.6 [rev/s] power losses, shaft speed 15.6 [rev/s]

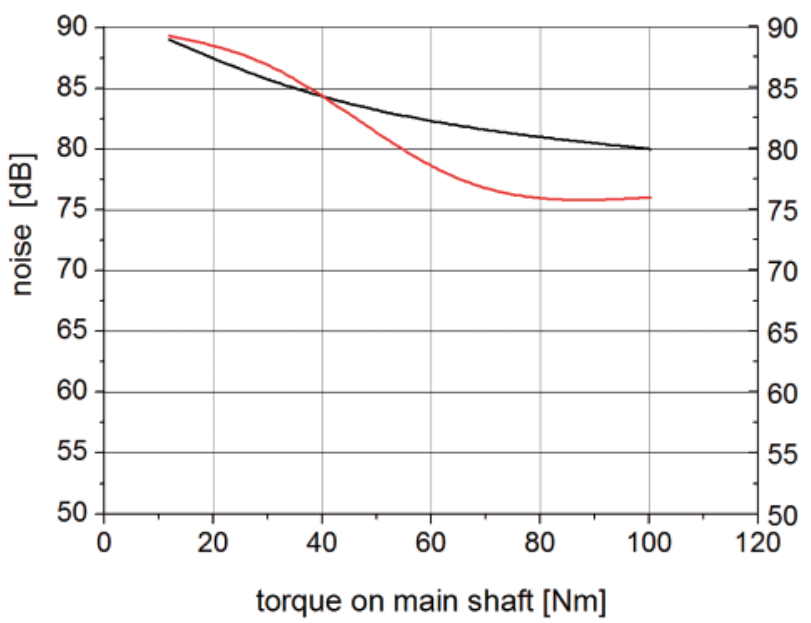

b) noise, shaft speed $12.4[\mathrm{rev} / \mathrm{s}]$ power losses, shaft speed 12.4 [rev/s]
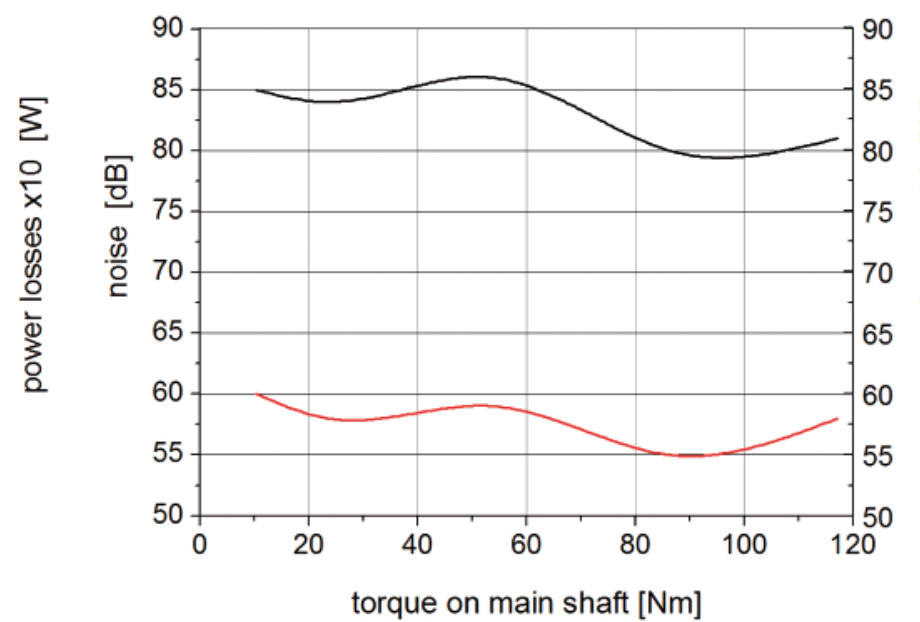

Fig. 12. Diagrams of lost power and measured noise of the drive system with straight gear belt (version I) as a function of the drive shaft torque and rotational speed: a) main shaft rotational speed $15.6 \mathrm{rev} / \mathrm{s}, \boldsymbol{b})$ main shaft rotational speed $12.4 \mathrm{rev} / \mathrm{s}$

a) — noise, shaft speed 15.6 [rev/s] power losses, shaft speed 15.6 [rev/s]

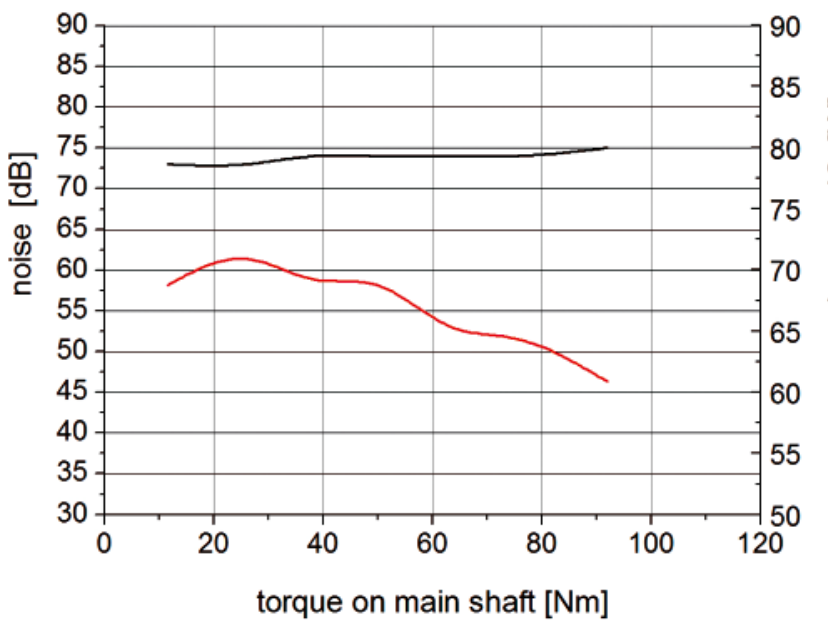

b) noise, shaft speed $12.4[\mathrm{rev} / \mathrm{s}]$

- power losses, shaft speed 12.4 [rev/s]

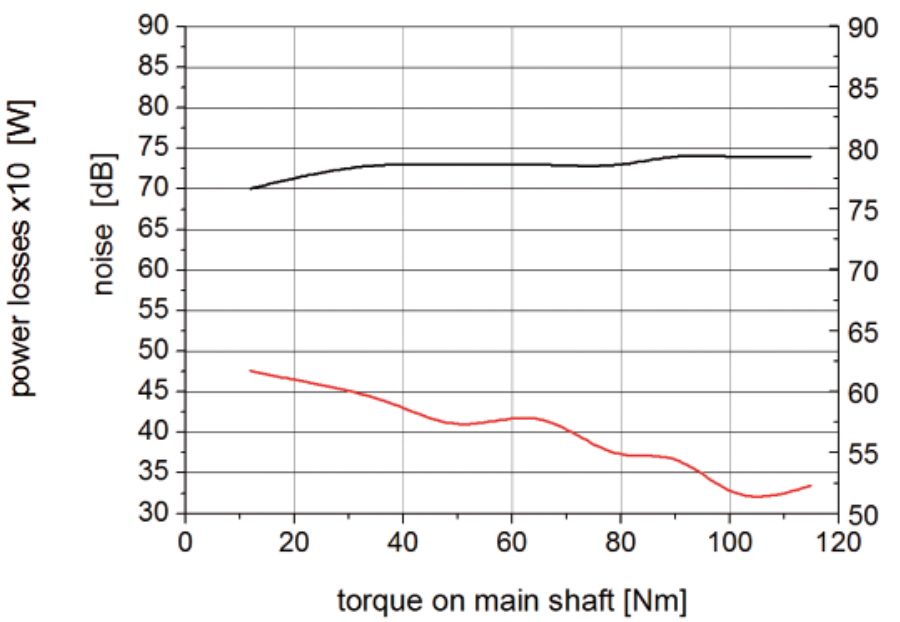

Fig. 13. Diagrams of lost power and measured noise of the drive system with bevel gear belt (version II) as a function of the drive shaft torque and rotational speed: a) main shaft rotational speed $15.6 \mathrm{rev} / \mathrm{s}, \boldsymbol{b})$ main shaft rotational speed $12.4 \mathrm{rev} / \mathrm{s}$

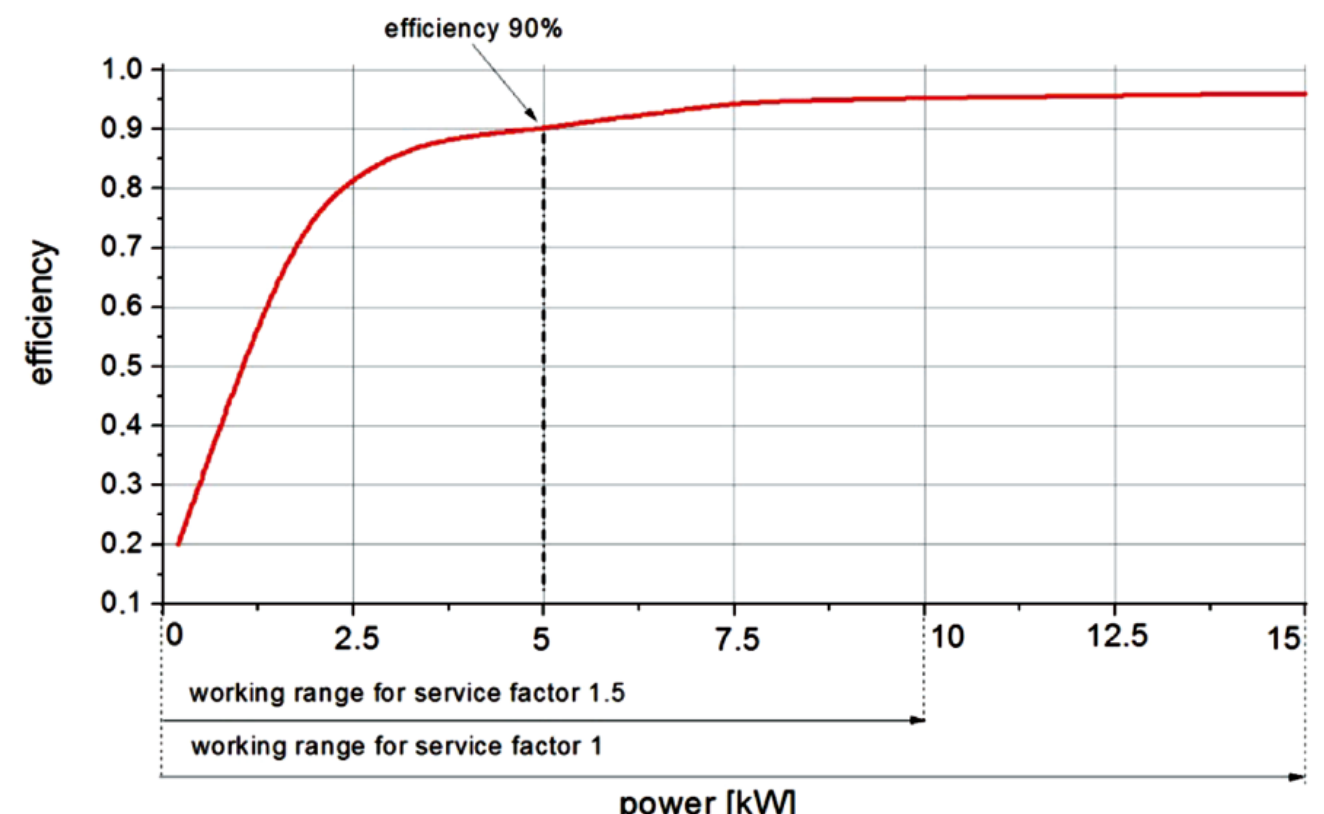

Fig. 14. Diagram of efficiency as a function of output power 


\section{SUMMARY AND CONCLUSIONS}

The energy efficiency of a battery-supplied ship propulsion system is of primary importance. Batteries have limited capacity and the accumulated energy must be utilized economically. Cases have been known where crews accustomed for years to operate ships with conventional propulsion could not cope with a battery or photovoltaic cell-supplied electric drive of ships.

In analysing the propulsion system overall efficiency it has to be remembered, that it is a product of the efficiencies of motor, transmission gear, bearings and screw propeller. If in a ship a high efficiency screw propeller with maximum efficiency of $65 \%$ were used, then in optimum conditions the overall propulsion system efficiency would not exceed $55 \%$.

The tested $11 \mathrm{~kW}$ electric motor reached efficiency exceeding $90 \%$ in the output power range above $5.5 \mathrm{~kW}$. Power of only about $10 \mathrm{~kW}$ was obtained during the tests. The motor did not achieve the catalogue rotational speed and torque. The Authors had experienced similar situations in the past, when the drive unit parameters differed from the catalogue values by more than $10 \%$. In some cases the operating parameters could be improved by reprogramming the frequency converter.

The investigations will be continued in order to compare properties of other two types of belt transmissions. Transmission with five wedge belts and transmission with a multi-wedge belt have already been designed.

\section{BIBLIOGRAPHY}

1. Psoma A., Sattler G.: Fuel cell systems for submarines: from the first idea to serial production; Journal of Power Sources 106, 2002

2. Kickulies M.: Fuel cell power for maritime applications; Fuel Cells Bulletin, September 2005

3. Weaver G.: Marine applications of fuel cell technology; Fuel Cells Bulletin, January 2003

4. McConnell Vicki P.: Now, voyager? The increasing marine use of fuel cells; Fuel Cells Bulletin, May 2010

\section{CONTACT WITH THE AUTHOR}

Jakub Kowalski, M. Sc.

Wojciech Leśniewski, Ph. D. Wojciech Litwin, Ph. D.

Faculty of Ocean Engineering and Ship Technology

Gdansk University of Technology Narutowicza 11/12 80-233 Gdansk, POLAND e-mail:wlitwin@pg.gda.pl 